\title{
Dulaglutide (LY-2189265) for the treatment of type 2 diabetes
}

\section{André J. Scheen}

To cite this article: André J. Scheen (2016): Dulaglutide (LY-2189265) for the treatment of type 2 diabetes, Expert Review of Clinical Pharmacology, DOI: 10.1586/17512433.2016.1141046

To link to this article: http://dx.doi.org/10.1586/17512433.2016.1141046

Accepted author version posted online: 13

Jan 2016.

Submit your article to this journal

Q View related articles $\asymp$

View Crossmark data 
Publisher: Taylor \& Francis

Journal: Expert Review of Clinical Pharmacology

DOI: $10.1586 / 17512433.2016 .1141046$

Drug Profile

Dulaglutide (LY-2189265) for the treatment of type 2 diabetes

\section{André J. Scheen (1,2)}

(1) Division of Diabetes, Nutrition and Metabolic Disorders, Department of Medicine, CHU Liège, Liège, Belgium

(2) Division of Clinical Pharmacology, Center for Interdisciplinary Research on Medicines (CIRM), University of Liège, Liège, Belgium

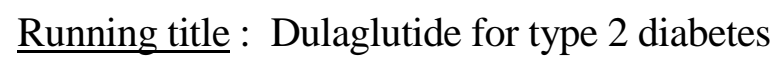

$\underline{\text { Address for correspondence : }}$

Pr André J. SCHEEN

Department of Medicine

CHU Sart Tilman (B35)

B-4000 LIEGE 1

BELGIUM

Phone : 32-4-3667238

FAX : 32-4-3667068

Email : andre.scheen @ chu.ulg.ac.be 


\section{ABSTRACT}

Dulaglutide is a,new once-weekly glucagon-like peptide-1 receptor agonist for the management of hyperglycemia in adult patients with type 2 diabetes. It stimulates dosedependent insulin secretion and reduces glucagon secretion, both in a glucose-dependent manner. Efficacy on blood glucose control and safety were demonstrated in the large AWARD program in type 2 diabetic patients treated with diet, metformin, dual oral therapy or insulin lispro with or without metformin, confirming findings of pilot studies in Caucasian patients and data in Japanese patients. Dulaglutide $1.5 \mathrm{mg}$ once weekly was superior to metformin, sitagliptin, insulin glargine and exenatide twice daily, and non-inferior to liraglutide $1.8 \mathrm{mg}$ once daily regarding the reduction in glycated hemoglobin. A modest but significant weight loss was consistently observed. Most frequent adverse events were transient and generally mild gastrointestinal disturbances. Clinical outcomes of dulaglutide will not be known until the large prospective cardiovascular outcome trial REWIND is complete.

Key-words : Dulaglutide - Clinical trial - GLP-1 receptor agonist - Insulin secretion - Once weekly injection - Therapy - Type 2 diabetes mellitus 


\section{Introduction}

Type 2 diabetes mellitus (T2DM) is increasingly prevalent worldwide and is linked to abdominal obesity in genetically predisposed individuals. [1] It is associated with a major burden for patients and society, mainly due to severe vascular complications that impair quality of life, reduce life expectancy and dramatically increase cost. [2] To prevent these complications, besides a global approach targeting all risk factors, guidelines for treating hyperglycemia recommend a patient-centered approach with metformin and lifestyle modifications as first-line therapy for most individuals. [2-4] Second-line agents are diverse and increasingly numerous. [3] Currently, in most countries, the clinician has the choice between sulfonylureas, thiazolidinediones, dipeptidyl peptidase-4 (DPP-4) inhibitors (gliptins), [5] sodium-glucose cotransporter type 2 (SGLT2) inhibitors (gliflozins), [6] glucagon-like peptide-1 receptor agonists (GLP-1 RAs), [7] and insulin. [3] Because combined therapy is needed in many patients with T2DM, various fixed dose combinations are also available, mainly but not exclusively including metformin. Drug properties, as well as patient-specific characteristics and preferences, should be considered during the selection of second-line agents and a similar approach may be used when considering moving towards triple therapy. [3] Effect on body weight and avoidance of hypoglycemia were identified among the most important factors driving patient preferences regarding pharmacological therapy of T2DM. [8] In this respect, the development of the GLP-1 RAs represents a substantial advancement in the treatment of T2DM, especially because these agents can improve glucose control, with a low risk of hypoglycemia, while promoting weight loss. $[1,7$, 9, 10] GLP-1, an incretin hormone, stimulates insulin secretion and suppresses glucagon secretion in a glucose-dependent manner while delaying gastric emptying and promoting satiety. [7] Whereas native GLP-1 is rapidly inactivated by the enzyme DPP-4, GLP-1 RAs are modified to resist inactivation by DPP-4. [7] Not all GLP-1 RAs are equal, with each having its own distinct pharmacokinetic and pharmacodynamic characteristics based on its molecular size. Schematically, they have been classified as short-acting and long-acting GLP1 RAs. [7] From a clinical point of view, the most obvious difference is that some GLP-1 RAs should be injected every day (exenatide immediate-release, liraglutide, lixisenatide) whereas others can be injected only once weekly (exenatide extended-release, albiglutide, dulaglutide, semaglutide). From a diabetic patient's perspective, once-weekly administration instead of 
daily injection may provide greater convenience, better medication adherence and improved quality of life. [11]

Dulaglutide (LY2189265, Trulicity ${ }^{\circledR}$ ) is a new long-acting human GLP-1 RA to be administered subcutaneously once weekly with the use of a pen device. [12-15] The objective of this review article is to summarize the pharmacology, pharmacokinetics, pharmacodynamics, clinical efficacy and safety of dulaglutide, including very recent data in a rapidly evolving field, and to put into perspective this compound in comparison with other GLP-1 RAs and glucose-lowering agents for the management of T2DM.

\section{Structure of dulaglutide}

Dulaglutide is a GLP-1 immunoglobulin G (IgG4) Fc fusion protein with extended pharmacokinetics and activity. [16] Dulaglutide molecule consists of two identical, disulfidelinked chains, each containing a human GLP-1 analog sequence covalently linked to a modified human immunoglobulin $\mathrm{G} 4$ (IgG4) heavy chain fragment $(\mathrm{Fc})$ by a small peptide linker (Figure 1). The GLP-1 analog portion of dulaglutide is approximately $90 \%$ homologous to native human GLP-1. Some few amino acid substitutions aim at optimizing its clinical profile, including improved solubility of the peptide, protection from dipeptidyl peptidase-4 (DPP-4) inactivation and reduced immunogenicity. The IgG-Fc increases the size of the molecule, thereby reducing the rate of clearance and drastically limiting its potential renal excretion. The IgG4 Fc portion of the molecule was also modified to prevent antibody formation and to reduce the potential for interaction with high affinity Fc receptors that may result in immunologic cytotoxicity. [17]

\section{Pharmacokinetics of dulaglutide}

\subsection{Healthy subjects and patients with T2DM}

Following a single $1.5 \mathrm{mg}$ subcutaneous dose administration in healthy volunteers, the absolute bioavailability of dulaglutide was found to be approximately $44 \%$, probably due to metabolism/degradation at the site of injection. [17] In healthy subjects, the half-life of dulaglutide was approximately $90 \mathrm{~h}$, with plasma maximum concentration $\left(\mathrm{C}_{\max }\right)$ occurring between 24 and 48 hours in most subjects. [18] 
A 5-week study evaluated the pharmacokinetics of dulaglutide in patients with T2DM. [19] The time to maximal plasma drug concentration $\left(t_{\max }\right)$ ranged from 12 to 72 hours and was similar between the first and the fifth dose. Assessment of trough dulaglutide concentrations indicated that steady-state plasma levels were obtained after the second weekly dose with an average accumulation ratio [area under the curve of plasma concentrations (AUC) at week 5 divided by the AUC at week 1] estimated to be 1.44 . The average peak-totrough concentration ratio $\left(\mathrm{C}_{\max }: \mathrm{C}_{\min }\right)$ was between two and three. The mean plasma half-life determined after the last dose was $95.4 \mathrm{~h}$ (approximately 4 days). The mean steady-state apparent clearance and volume of distribution were $0.157 \mathrm{l} / \mathrm{h}$ and $21.5 \mathrm{l}$, respectively. The intra-subject variability for $\mathrm{C}_{\max }$ and $\mathrm{AUC}_{(0-168 \mathrm{~h})}$ were 29.4 and $14.6 \%$, respectively; corresponding values for intersubject variability were 28.5 and $30.8 \%$, respectively. [19]

Overall, these results were confirmed in pharmacokinetic meta-analysis of Phase 1 data and population pharmacokinetic modeling of Phase 2 and Phase 3 studies. [20] The pharmacokinetics of dulaglutide was well described by a 2-compartment model with firstorder absorption. After subcutaneous injection, dulaglutide was slowly absorbed and $\mathrm{t}_{\max }$ at steady state ranged from 24 to 72 hours (median $=48$ hours). The absolute bioavailability was $47 \%$ and the half-life was estimated at 4.7 days. Steady state was achieved between 2 and 4 weeks of dosing and the accumulation ratio was approximately 1.56. Mean volume of distribution after intravenous administration was $5.32 \mathrm{~L}$, suggesting dulaglutide distributes primarily in the blood volume. Apparent clearance in patients with T2DM after multiple 1.5 mg dosing was $0.107 \mathrm{~L} / \mathrm{hr}$. Body weight influenced dulaglutide pharmacokinetics, although weight explained $<6 \%$ of the inter-patient variability. Effects of age, body weight, sex, race and ethnicity on dulaglutide pharmacokinetics were not clinically relevant. Furthermore, injection site (abdomen, upper arm, thigh) had no statistically significant effect on exposure. Thus, the PK of dulaglutide $1.5 \mathrm{mg}$, especially its long half-life, supports once weekly administration in patients with T2DM and no dose adjustment is needed based on body weight, sex, age, race or ethnicity, or injection site. [17]

\subsection{Subjects with renal insufficiency}

Dulaglutide pharmacokinetics (after a single $1.5 \mathrm{mg}$ subcutaneous dose) was examined in subjects with mildly impaired (estimated creatinine clearance or CrCL: $50-80 \mathrm{~mL} / \mathrm{min}$; $\mathrm{n}=8$ ), moderately impaired (CrCL: 30-50mL/min; $\mathrm{n}=8$ ), severely impaired renal function (CrCL: $<30 \mathrm{~mL} / \mathrm{min} ; \mathrm{n}=8$ ) or end stage renal disease requiring dialysis $(\mathrm{n}=8)$, and a control 
group ( $n=16)$ with normal renal function. No relationship was observed between the main pharmacokinetic parameters $\left(\mathrm{C}_{\max }\right.$ and total exposure reflected by AUC) and renal function based on estimated glomerular filtration rate. Overall, the results suggest that kidneys play a less important role in the elimination of dulaglutide, which is not unexpected given the large size of the protein. Consequently, dose adjustment in patients with mild to moderate renal impairment is not necessary. [17, 21]

\subsection{Subjects with hepatic impairment}

Dulaglutide pharmacokinetic parameters (again after a single $1.5 \mathrm{mg}$ subcutaneous dose) were compared between subjects with mild hepatic impairment (Child-Pugh $A, n=6$ ), moderate hepatic impairment (Child-Pugh B; n=6), severe hepatic impairment (Child-Pugh C, $\mathrm{n}=3)$, and a control group with normal hepatic function $(\mathrm{n}=11)$. No increase in the dulaglutide exposure was seen in patients with hepatic impairment. On the contrary, statistically significant decreases in exposure were observed in all three hepatic impairment groups compared to healthy controls. [17]

\subsection{Subjects exposed to drug-drug interactions}

The elimination of dulaglutide is expected to be through proteolytic degradation into its amino acid components. Dulaglutide is not anticipated to be eliminated intact in the urine or to be metabolized by the CYP enzymes. Therefore, pharmacokinetic interactions with drugs primarily eliminated by the kidneys or metabolized by liver CYP enzymes are unlikely. However, dulaglutide causes a delay in gastric emptying, which may alter the pharmacokinetics of orally co-administered drugs, a condition that may be clinically important for drugs with a narrow therapeutic index. [17]

\section{Pharmacodynamics of dulaglutide}

\subsection{Effect on insulin secretion}

In vitro and in vivo studies on T2DM models demonstrated glucose-dependent insulin secretion stimulation. In healthy subjects, pharmacodynamic parameters (plasma glucose and insulin concentrations) were measured following a step-glucose intravenous infusion and as part of an oral glucose tolerance test (OGTT). [18] Following a stepped glucose infusion, there were dose-dependent decreases in glucose concentrations and increases in insulin 
concentrations with time and the time-matched insulin to glucose ratio showed a rapid increase in a dose-dependent fashion. [18] Evidence of increase in glucose-dependent insulin secretion and suppression of serum glucose excursions were also observed during an OGTT at all doses compared to placebo (doses ranging from 0.1 to $12 \mathrm{mg}$ ). [18] In T2DM patients treated with diet or metformin, following standard test meals, dulaglutide produced statistically significant increases in plasma insulin and C-peptide AUC when normalized for glucose AUC. [19]

Measures of B-cell function and insulin sensitivity were estimated using the HOMA (Homeostasis Model Assessment) approach in several studies having evaluated dulaglutide. In two pilot dose-response 12-week studies in T2DM patients on diet and exercise, significant dose-dependent increases in HOMA2-\%B (evaluating B-cell insulin secretory capacity) were observed across the dulaglutide groups receiving $0.1,0.5,1.0$ and $1.5 \mathrm{mg}$ once weekly in Caucasian patients [22] and receiving $0.5,1.0$ and $1.5 \mathrm{mg}$ once weekly in Japanese patients. [23] In patients with T2DM treated with diet and exercise in the 26-week AWARD-3 trial, HOMA2-\%B increased in all treatment arms, but changes with dulaglutide $1.5 \mathrm{mg}$ and dulaglutide $0.75 \mathrm{mg}$ were greater than with metformin ( $\mathrm{P}<0.001$, both comparisons $)$. [24] HOMA2-\%S (an index of insulin sensitivity) also increased in the three arms, with greater changes with metformin compared with dulaglutide. Results were similar for the index of insulin secretion at 52 weeks, whereas the difference in the insulin sensitivity index between dulaglutide $1.5 \mathrm{mg}$ and metformin was no longer significant. [24] In AWARD-5 trial [25] comparing dulaglutide ( 0.75 and $1.5 \mathrm{mg}$ once weekly) with placebo and sitagliptin in T2DM patients on metformin monotherapy, HOMA2-\%B at 52 weeks increased numerically in all arms versus baseline, but the changes observed were significantly greater with both dulaglutide doses compared with sitagliptin $100 \mathrm{mg}$ ( $\mathrm{P}<0.001)$. In contrast, no differences were observed among arms with respect to insulin sensitivity of the peripheral tissues, estimated by HOMA2-\%S. [25] Almost similar results were obtained in the EGO 16-week trial comparing dulaglutide with placebo in patients with T2DM already treated with two oral antidiabetic agents, with significant increases of HOMA2-\%B and no significant increase in HOMA2-\%S versus placebo. [26]

\subsection{Effect on glucagon secretion}


Dulaglutide can lower blood glucose by stimulating insulin secretion but also by decreasing glucagon secretion. In the AWARD-3 study in T2DM patients treated with diet and exercise, at 26 weeks, fasting glucagon decreased with dulaglutide $1.5 \mathrm{mg}$ and dulaglutide $0.75 \mathrm{mg}$ and was unchanged in the metformin group ( $\mathrm{P}<0.001$, both comparisons) while at 52 weeks, similar glucagon decreases were observed in the three treatment arms. [24] In addition, decreases in postprandial glucagon AUC (0-3 hours post-meal) were observed following a standardized test meal in this study. After 26 and 52 weeks of treatment with dulaglutide $1.5 \mathrm{mg}$, least squares mean decreases in glucagon AUC from baseline were -5.91 pmol.h/L and - 8.04 pmol.h/L, respectively. [17] No such reductions in plasma glucagon levels were observed with the active comparator metformin.

\subsection{Effect on gastric emptying}

The effect of dulaglutide (1.5 mg subcutaneously once weekly for 4 weeks) has been evaluated on gastric emptying using scintigraphy. [17] Repeat scintigraphy (following a radiolabeled breakfast) at the time of the expected dulaglutide $t_{\max }$ showed statistically significant delays in gastric emptying rate following each of four $1.5 \mathrm{mg}$ dulaglutide doses compared to baseline. The greatest delay was observed after the first dose, with a trend to decrease from the second dose onwards. [17]

\subsection{Effect on fasting and postprandial glycemia}

Once-weekly administration of dulaglutide $(0.05,0.3,1,3,5$ or $8 \mathrm{mg})$ significantly reduced fasting plasma glucose, 2-h post-test meal postprandial glucose and AUC of plasma glucose concentrations after test meals at doses $\geq 1 \mathrm{mg}$ in patients with T2DM treated with lifestyle measures with or without metformin. These effects were seen after the first dose and were sustained through the weekly dosing cycle for 5 weeks. [19] These data were confirmed in a 12-week dose-response trial performed where dose-dependent reductions in fasting, premeal and post-meal plasma glucose were observed, with tested dulaglutide doses being 0.1 , $0.5,1.0$ or $1.5 \mathrm{mg}$. [22] Dulaglutide at a dose of 1.0 or $2.0 \mathrm{mg}$ administered once weekly for 16 weeks has been shown to have a robust effect on fasting plasma glucose as well as on glucose excursions after a meal test. [26]

\section{Clinical efficacy}


The clinical efficacy of dulaglutide, i.e its glucose-lowering activity assessed by reductions in fasting and postprandial glucose plasma concentrations and HbA1c levels combined with the body weight reducing effect, of dulaglutide has been carefully investigated in patients with T2DM in the AWARD program (Table 1). Background therapy varied according to the trial with T2DM patients treated with diet and exercise only (dulaglutide as monotherapy) (AWARD-3), [24] with metformin alone (dulaglutide as add-on therapy, i.e. dual therapy) (AWARD-5 and AWARD-6), [25] [27] with metformin + glimepiride (AWARD-2) [28] or metformin + pioglitazone (AWARD-1) [29] (i.e. dulaglutide as triple therapy) or with insulin with or without metformin (AWARD-4). [30] Trials comparing dulaglutide with other active glucose-lowering agents were primarily designed as noninferiority trials. Patients recruited for AWARD trials were typically Caucasian T2DM patients with a mean age between 55 and 60 years, a mean duration of diabetes between 3 and 13 years and a mean body mass index around $33 \mathrm{~kg} / \mathrm{m}^{2}$. [23, 25, 27-30] Other pilot trials of smaller size have been also performed in Caucasian T2DM patients on diet alone [22] or on two oral antidiabetic agents [26].

It is important to also analyze the clinical efficacy of dulaglutide in the Asian population because of possible differences in the two major pathophysiological components (defective insulin secretion versus insulin resistance) of T2DM in Asian compared with Caucasian people [31]. A recent meta-analysis of clinical trials with GLP-1 analogues showed indeed a greater $\mathrm{HbA1c}$ reduction in Asian-dominant studies than in non-Asian-dominant studies [32]. Recently results of clinical trials with dulaglutide have been reported in Japanese patients with T2DM treated with diet alone [23, 33] or with sulfonylurea and/or metformin are also available (Table 2 and Table 3 ). [34, 35]

\subsection{T2DM inadequately controlled with diet and exercise}

In a 12-week, double-blind, placebo-controlled, dose-response trial, dose-dependent reductions in $\mathrm{HbA1c}$, fasting plasma glucose and body weight were observed with dulaglutide $(0.1,0.5,1.0$ and $1.5 \mathrm{mg}$ once weekly versus placebo) in T2DM patients treated with diet alone (Table 2). [22] Similar findings were reported in Japanese patients with diet-treated T2DM in a 12-week trial comparing dulaglutide $(0.25,0.50$ and $0.75 \mathrm{mg}$ once weekly) with placebo (Table 2). [23] In AWARD-3, dulaglutide (0.75 mg or $1.5 \mathrm{mg}$ once weekly) was compared with metformin (progressively titrated up to 2,000 mg/day during the first 4 weeks 
of treatment or at least $1,500 \mathrm{mg} /$ day depending upon tolerability) in a double-blind 52-week trial (primary endpoint at 26 weeks) in patients with T2DM treated with diet alone or a small dose of an oral antihyperglycemic medication (discontinued before the study). Dulaglutide 1.5 and $0.75 \mathrm{mg}$ were superior to metformin in reducing $\mathrm{HbA} 1 \mathrm{c}$ level and greater percentages of patients reached $\mathrm{HbA} 1 \mathrm{c}$ targets $<7.0 \%$ and $\leq 6.5 \%$ with dulaglutide 1.5 and $0.75 \mathrm{mg}$ compared with metformin ( $\mathrm{P}<0.05$, all comparisons) (Table 1). [24] In a phase 3, randomized, doubleblind, placebo-controlled, open-label comparator (liraglutide) trial in Japanese patients with T2DM treated with diet alone, once weekly dulaglutide $(0.75 \mathrm{mg})$ was superior to placebo and non-inferior to once daily liraglutide $(0.9 \mathrm{mg}$, dose recommended in Japan) for reduction in HbA1c at 26 weeks (primary endpoint) (Table 2). [33] In another longer 52-week trial in Japanese patients treated with diet or oral monotherapy (excluding glitazone), dulaglutide $0.75 \mathrm{mg}$ once weekly was associated with a greater reduction in HbAlc compared with liraglutide $0.9 \mathrm{mg}$ once daily (mean difference : $-0.20 \%$; $95 \%$ CI -0.39 to $-0.01 ; \mathrm{p}=0.04$ ) (Table 3). [35]

All these data demonstrate that dulaglutide as monotherapy improves glycemic control in patients with early stage T2DM. Dulaglutide once weekly was superior to placebo and metformin and non-inferior (or even slightly superior in one Japanese trial) to liraglutide once daily.

\subsection{T2DM inadequately controlled with metformin alone}

AWARD-5 was an adaptive, seamless, double-blind study comparing dulaglutide with placebo at 26 weeks and sitagliptin up to 104 weeks in T2DM patients not well controlled with metformin monotherapy $\geq 1500 \mathrm{mg}$ /day. [25, 36] The study also included a dose-finding portion. [37] A Bayesian algorithm allowed for an efficient exploration of a large number of doses and selected dulaglutide doses of 1.5 and $0.75 \mathrm{mg}$ for further investigation in this trial. [37] The primary objective of AWARD-5 was to compare (for non-inferiority and then superiority) dulaglutide $1.5 \mathrm{mg}$ versus sitagliptin in change from baseline in $\mathrm{HbA} 1 \mathrm{c}$ at 52 weeks. [25] Both $0.75 \mathrm{mg}$ and $1.5 \mathrm{mg}$ doses of dulaglutide were superior to sitagliptin $100 \mathrm{mg}$ ( $\mathrm{p}<0.001$, both comparisons) (Table 1). No events of severe hypoglycemia were reported with dulaglutide. Mean weight changes at 52 weeks were greater with dulaglutide $1.5 \mathrm{mg}$ and dulaglutide $0.75 \mathrm{mg}$ compared with sitagliptin ( $\mathrm{P}<0.001$, both comparisons) (Table 1 ). These results were confirmed at the final endpoint of 104 weeks. [36] Indeed, changes in $\mathrm{HbAlc}$ at 104 weeks were $-0.99 \pm 0.06 \%,-0.71 \pm 0.07 \%$ and $-0.32 \pm 0.06 \%$ (least squares 
mean \pm standard error) for dulaglutide $1.5 \mathrm{mg}$, dulaglutide $0.75 \mathrm{mg}$ and sitagliptin $100 \mathrm{mg}$, respectively ( $p<0.001$, both dulaglutide doses versus sitagliptin). Weight loss at 104 weeks was greater with dulaglutide $1.5 \mathrm{mg}(\mathrm{p}<0.001)$ and similar with dulaglutide $0.75 \mathrm{mg}$ versus sitagliptin $(2.88 \pm 0.25,2.39 \pm 0.26$ and $1.75 \pm 0.25 \mathrm{~kg}$, respectively). [36]

AWARD-6 is a head-to-head, open-label, phase 3, non-inferiority trial, which compared the efficacy and safety of once-weekly dulaglutide $1.5 \mathrm{mg}$ with once-daily liraglutide 1.8 $\mathrm{mg}$ in patients with uncontrolled T2DM despite metformin $\geq 1500 \mathrm{mg} /$ day. [27] The primary outcome was non-inferiority (margin $0.4 \%$ ) of dulaglutide compared with liraglutide for change in HbA1c at 26 weeks. Least-squares mean reduction in HbA1c was similar in the two treatment groups (Table 1), demonstrating the non-inferiority of dulaglutide $1.5 \mathrm{mg}$ once weekly compared with liraglutide $1.8 \mathrm{mg}$ once daily. The hypoglycemia rate was similarly low in the two treatment groups, and no severe hypoglycemia was reported. Weight reduction was significantly more pronounced with liraglutide than with dulaglutide (Table 1). [27]

\subsection{T2DM inadequately controlled with metformin plus sulfonylurea}

In a placebo-controlled, double-blind 16-week trial (EGO study) [26] in T2DM patients not well controlled with two oral antidiabetic medications (metformin plus sulfonylurea in almost $75 \%$ of patients), dulaglutide significantly and dose-dependently reduced HbA1c levels and fasting and postprandial glucose concentrations compared with placebo (Table 2). Hypoglycemia was uncommon overall ( $</=0.8$ episodes/patient $/ 30$ days) but two- to threefold more common (especially during the initial 4 weeks, although not severe) with dulaglutide than placebo throughout the 16-week study period. A dose-dependent weight loss was also observed with dulaglutide after 16 weeks (Table 2). [26]

AWARD-2 compared the efficacy and safety of two doses of dulaglutide once weekly with daily insulin glargine, both combined with maximally tolerated doses of metformin and glimepiride in patients with T2DM. [28] Concerning the HbA1c change from baseline at 52 weeks (primary objective), statistical criteria for superiority were met with dulaglutide $1.5 \mathrm{mg}$ and for noninferiority with dulaglutide $0.75 \mathrm{mg}$ compared with glargine (Table 1). More patients on dulaglutide $1.5 \mathrm{mg}$ achieved $\mathrm{HbA1c}$ targets $<7.0 \%$ versus glargine $(\mathrm{P}<0.001)$. However, in AWARD-2, glargine was used without forced titration (mean daily dose at 52 weeks : 29 UI). Body weight decreased with dulaglutide and increased with glargine (Table 1). Total and nocturnal hypoglycemia rates were lower with dulaglutide than with glargine, 
with almost no severe hypoglycemia. Similar findings were reported at the final endpoint of 78 weeks. [28]

The results of AWARD-2 were confirmed in another randomized, open-label, phase 3, non-inferiority study in Japanese patients with T2DM treated with sulfonylurea and/or biguanide (metformin). [34] At week 26, the reduction in HbA1c was significantly greater with dulaglutide $0.75 \mathrm{mg}$ once weekly than with glargine (Table 2). However, the mean daily dose of glargine at endpoint was rather low (only $12.5 \mathrm{UI} /$ day). Nevertheless, the incidence of hypoglycemia was significantly $(\mathrm{P}<0.001)$ lower with dulaglutide $(26 \%)$ than with glargine $(48 \%)$. Furthermore, dulaglutide significantly reduced body weight compared with glargine at week 26 (Table 2). [34]

\subsection{T2DM inadequately controlled with metformin plus pioglitazone}

In AWARD-1 among T2DM patients treated with metformin (1,500-3,000 mg/day) and pioglitazone (30-45 mg/day), 0.75 and $1.5 \mathrm{mg}$ dulaglutide doses once weekly were superior to placebo at 26 weeks (primary endpoint) in reducing HbA1c (both $\mathrm{P}<0.001$ ) and also superior to exenatide $10 \mu \mathrm{g}$ twice daily at 26 and 52 weeks (both $\mathrm{P}<0.001$ ) (Table 1). Greater percentages of patients reached HbA1c targets with dulaglutide $1.5 \mathrm{mg}$ and $0.75 \mathrm{mg}$ than with placebo and exenatide (all $\mathrm{P}<0.001$ ). [29] Weight loss was lower with dulaglutide $0.75 \mathrm{mg}$ and similar with dulaglutide $1.5 \mathrm{mg}$ once weekly as compared with exenatide $10 \mu \mathrm{g}$ twice daily (Table 1).

\subsection{T2DM inadequately controlled with prandial insulin}

AWARD-4 was a randomized, open-label, phase 3, non-inferiority study, which aimed to compare the efficacy and safety of dulaglutide with that of insulin glargine, both combined with prandial insulin lispro, in patients with T2DM (receiving or not metformin). [30] At 26 weeks, the adjusted mean change in HbA1c was greater in patients receiving dulaglutide 1.5 $\mathrm{mg}$ and dulaglutide $0.75 \mathrm{mg}$ than in those receiving glargine (Table 1). The proportion of patients achieving an $\mathrm{HbA} 1 \mathrm{c}$ target of less than $7 \cdot 0 \%$ was significantly greater in both the dulaglutide $1.5 \mathrm{mg}$ and $0.75 \mathrm{mg}$ groups versus glargine whose dose was titrated up to a mean of 64 units/day $(\mathrm{P}=0.014$ and $\mathrm{P}=0.010$, respectively). Similar results were noticed at 52 weeks. The reductions in the mean of all fasting and pre-meal plasma glucose concentrations were significantly greater with glargine, whereas the decrease in the mean of all postprandial 
glucose values was significantly greater with dulaglutide $1.5 \mathrm{mg}$. However, it is noteworthy that the doses of preprandial lispro were less in the glargine group and in the two dulaglutide groups. Patients treated with dulaglutide $1.5 \mathrm{mg}$ lost weight, those on dulaglutide $0.75 \mathrm{mg}$ maintained their body weight and those on glargine gained weight after 26 and 52 weeks (Table 1). The rates of total and nocturnal hypoglycemia were significantly lower in the 1.5 mg dulaglutide group than in the glargine group at both 26 and 52 weeks $(\mathrm{P}<0.001)$. [30] The conclusion was that dulaglutide in combination with lispro with or without metformin resulted in a significantly greater improvement in glycemic control than did glargine. Thus, it may represent a new treatment option for patients unable to achieve glycemic targets withinsulin therapy.

\section{Tolerance and safety of dulaglutide}

Overall, the safety profile of dulaglutide in clinical trials was similar to that of currently available GLP-1 RAs, characterized predominantly by gastrointestinal symptoms. [12-15] Nausea, vomiting and diarrhea were all significantly more common in patients taking dulaglutide 1.5 and $0.75 \mathrm{mg}$ compared with placebo, and slightly more frequent with the higher dose of dulaglutide compared with the lower dose. However, gastrointestinal adverse events were mostly mild to moderate and transient in nature. In the six landmark trials of the AWARD program, rates of nausea ranged from $15.4 \%$ to $28 \%$ and from $7.7 \%$ to $17.7 \%$ in the dulaglutide $1.5 \mathrm{mg}$ and $0.75 \mathrm{mg}$ groups, respectively. Vomiting was less common, occurring in $7 \%$ to $17 \%$ of patients in the dulaglutide $1.5 \mathrm{mg}$ group and $5.9 \%$ to $10.6 \%$ in the dulaglutide $0.75 \mathrm{mg}$ group. Diarrhea occurred in $10 \%$ to $16.6 \%$ and $5.2 \%$ to $15.7 \%$ of patients receiving dulaglutide $1.5 \mathrm{mg}$ and $0.75 \mathrm{mg}$, respectively. No clear-cut differences in gastrointestinal complaints were observed between dulaglutide $1.5 \mathrm{mg}$ and exenatide immediate-release (10 $\mu \mathrm{g}$ injected twice daily) in AWARD-1 [29] and liraglutide (1.8 mg once daily) in AWARD-6. [27] However, both exenatide and liraglutide required initial titration to minimize gastrointestinal side effects, which was not the case with dulaglutide.

Dulaglutide as a GLP-1 RA stimulates insulin secretion and inhibits glucagon secretion

in a glucose-dependent manner. [7] This explains the low risk of hypoglycemia, almost similar to that observed with placebo (AWARD-1 and AWARD-5), [25, 29] metformin (AWARD-3) [24] or sitagliptin (AWARD-5) [25] and lower than that observed with insulin glargine (AWARD-2 and AWARD-4). [28, 30] Overall, rates of hypoglycemia with dulaglutide were higher in the AWARD trials that included background therapies known to 
cause hypoglycemia, such as insulin and sulfonylureas (AWARD-2 and AWARD-4). [28] [30] In those patients already on insulin or sulfonylurea, the risk of hypoglycemia when adding dulaglutide could be minimized by an initial reduction of the doses of insulin or sulfonylureas, especially if $\mathrm{HbA1c}$ level is not markedly elevated. Of major interest, there were no reports of severe hypoglycemia occurring in any trial of the AWARD program with dulaglutide.

Injection-site reactions (hematoma, injection site reaction, erythema) in patients receiving dulaglutide were scarce in currently available clinical trials $(1.7 \%$ versus $0.9 \%$ with placebo), [17] and apparently much less frequent as compared to exenatide extended release using the technique of microspheres. [38] As with other GLP-1 RAs, development of antibodies against the medication may potentially lead to reduced efficacy and/or changes in the safety profile. The risk with dulaglutide appears to be low in trials that measured antibodies, presumably because of the nature of the product (see above section 2. Structure of dulaglutide). Only one skin hypersensitivity reaction occurred among patients participating to the AWARD program. [22]

Increases in pancreatic enzymes may be noticed among patients taking dulaglutide $(1.5 \%$ versus $0.7 \%$ in all comparators). [17] However, the cases of pancreatitis were rare in the AWARD program and in phase 2-3 clinical studies, although apparently more frequent in patients receiving dulaglutide compared with other glucose-lowering drugs (confirmed pancreatitis occurred in 5 patients taking dulaglutide and in 1 patient taking a nonincretin agent). [14, 17] Therefore, the US Food and Drug Administration has required the inclusion of this risk in the Risk Evaluation and Mitigation Strategy program for dulaglutide, as it was already requested for other GLP-1 RAs.

Overall, treatment of T2DM patients with dulaglutide in clinical trials did not alter kidney function or increase rates of adverse events related to kidney disease. [39] The cardiovascular safety of dulaglutide appears good, with no alarming signal noticed in the AWARD program, except a slight increase in heart rate. In AWARD trials, dulaglutide 1.5 mg weekly compared with placebo was found to reduce systolic blood pressure (least squares mean $=-2.8 \mathrm{~mm} \mathrm{Hg} ; \mathrm{P} \leq 0.001$ ) and increase heart rate (least squares mean $=+2.8 \mathrm{bpm} ; \mathrm{P}<$ 0.05). No significant differences were seen in blood pressure or heart rate when comparing dulaglutide with metformin, exenatide and liraglutide. After 52 weeks of therapy in AWARD5 , both doses of dulaglutide $1.5 \mathrm{mg}$ and $0.75 \mathrm{mg}$ were associated with a slight increase in 
heart rate compared with sitagliptin $100 \mathrm{mg}(+2.4,+2.1,-0.3 \mathrm{bpm}$, respectively; $\mathrm{P}<0.001)$. [25] In a 16-week, randomized, double-blind, multicenter, placebo-controlled study specifically designed to investigate the hemodynamic changes induced by dulaglutide, [40] the dose of $1.5 \mathrm{mg}$ once weekly was found to reduce systolic blood pressure (least squares mean $=-2.8 \mathrm{~mm} \mathrm{Hg}$ versus placebo; $\mathrm{P} \leq 0.001$ ) and increase heart rate (least squares mean $=$ +2.8 bpm versus placebo; $\mathrm{P}<0.05)$, thus confirming the findings of the placebo-controlled AWARD trials. The clinical significance of these minor changes is unknown. In a prespecified meta-analysis of prospectively adjudicated cardiovascular events in 9 randomized safety and efficacy trials (dulaglutide: $\mathrm{n}=3885$; all comparators [active or placebo]: $n=2125)$, treatment with dulaglutide was not associated with an increase in the risk of experiencing a composite of death due to cardiovascular causes, nonfatal myocardial infarction, nonfatal stroke, or hospitalization for unstable angina compared with control therapies (HR: 0.57; adjusted 98.02\% CI: 0.30, 1.10) [41]. The cardiovascular safety of dulaglutide will be further investigated in the ongoing cardiovascular outcome trial REWIND (Researching Cardiovascular Events With a Weekly Incretin in Diabetes) (see below section : Five year view).

\section{Drug formulation and dosing}

Dulaglutide is commercialized as a $0.75 \mathrm{mg} / 0.5 \mathrm{~mL}$ or $1.5 \mathrm{mg} / 0.5 \mathrm{~mL}$ solution in a prefilled automatic injection device. [17] The product does not require reconstitution, in contrast with exenatide extended-release. [38] The single-dose pen can be stored at room temperature for up to 14 days. The device is easy to be used : it extends a needle, delivers dulaglutide, and retracts the needle with the push of a button, so that patients have not to handle a needle. The dulaglutide single-dose pen was found to be a safe and effective device for use by patients with T2DM who were injection-naive. [42]

Dulaglutide has to be injected subcutaneously once-weekly at any time of day, without regard to meals, into the abdomen, thigh, or upper arm. The initial starting dose is $0.75 \mathrm{mg}$ once weekly, but the dose can be increased to $1.5 \mathrm{mg}$ once weekly if additional glycemic control is needed. In Europe, the recommended dose is $0.75 \mathrm{mg}$ once weekly as monotherapy and $1.5 \mathrm{mg}$ once weekly as add-on therapy. However, for potentially vulnerable populations, such as patients $\geq 75$ years, $0.75 \mathrm{mg}$ once weekly can be considered as a starting dose. [21] Missed doses should be administered within 3 days or the patient has to wait for the next once weekly injection. No dose adjustments are needed in patients with mild or moderate renal 
impairment. However, dulaglutide is not recommended in severe renal impairment (due to very limited experience in that group). [17, 21]

\section{Conclusion}

Dulaglutide is a new once-weekly GLP-1 RA approved by the US FDA and the EMA for the management of hyperglycemia in T2DM. Doses of 0.75 and $1.5 \mathrm{mg}$ once-weekly have demonstrated $\mathrm{HbA}_{1 \mathrm{c}}$ reduction of $\sim 0.7 \%-1.6 \%$ as monotherapy or in combination (dual or triple therapy) in controlled clinical trials. The glucose-lowering activity involves both reductions of fasting and postprandial plasma glucose concentrations, with a low risk of hypoglycemia. Compared with other GLP-1 RAs in the class, especially liraglutide once daily, it has been shown to be overall non-inferior for both safety and efficacy. It has been proven more effective than insulin glargine, however not uptitrated to target. As with other GLP-1 RAs, most common adverse events are transient gastrointestinal disturbances (nausea, diarrhea). Similar to other GLP-1 RAs, dulaglutide has demonstrated quite rapid and sustained weight loss of $\sim 1.5-3 \mathrm{~kg}$, contrasting with a weight increase with insulin glargine. In conclusion, dulaglutide is a novel option for treating T2DM that is easy for use, effective, well tolerated. It should be located alongside other long-acting GLP-1 RAs within the recommended guidelines.

\section{Expert commentary}

Current guideline recommendations place GLP-1 RAs as second-line therapy behind first-line metformin, as third-line therapy after failure of dual oral therapy or even as add-on to insulin for a majority of patients with T2DM. [3] [4] GLP-1 RAs lower both fasting and postprandial plasma glucose, but each formulation may differ in the extent to which it lowers the glucose level. [43] Available data from clinical trials with dulaglutide confirm that the compound lowers both fasting and postprandial glucose levels although the reduction in fasting plasma glucose concentrations appears to be more consistent than the decrease of postprandial glucose levels. [26] Besides the glucose-lowering effect with no or only little increase of hypoglycemia, dulaglutide, as other GLP-1 RAs, offers the advantage of a significant reduction in body weight, an effect that could positively affect other weight-related risk factors [9] and also possibly patient's preference and quality of life [8]. However, longterm evaluation of the relevant composite end-points including health-related quality of life 
and cost-effectiveness remain to be investigated in adequately powered, prospective, controlled clinical trials. [44]

Several once weekly GLP-1 RAs are currently available (exenatide extended-release, albiglutide, dulaglutide) and others are in late phase of development (semaglutide). [43] No clinical trial directly compared the efficacy and safety of these once weekly GLP-1 RAs but each of three compounds already commercialized has been compared in head-to-head trials with the once- daily GLP-1 RA liraglutide (at the maximum dose of $1.8 \mathrm{mg}$ for treating T2DM) used as reference (Table 3) [45]. Although $2 \mathrm{mg}$ exenatide extended-release [46] and $30 \mathrm{mg}$ albiglutide [47] failed to reach non-inferiority versus liraglutide $1.8 \mathrm{mg}$ [26], $1.5 \mathrm{mg}$ dulaglutide succeeded in AWARD-6, all studies being performed in metformin-treated T2DM patients [45]. Indeed, dulaglutide $1.5 \mathrm{mg}$ once weekly proved to be non-inferior to liraglutide $1.8 \mathrm{mg}$ once daily regarding the reduction in $\mathrm{HbA1c}$ level although liraglutide was accompanied by a slightly but significantly greater weight loss compared with dulaglutide (Table 3) [26]. In Japanese patients, dulaglutide once weekly showed also similar or even better efficacy in reducing HbA1c compared with liraglutide once daily. [33, 35] From these respective comparisons with liraglutide $1.8 \mathrm{mg}$, one might hypothesize that dulaglutide 1.5 $\mathrm{mg}$ is more potent than exenatide extended-release $2 \mathrm{mg}$ or albiglutide $30 \mathrm{mg}$ in improving hyperglycemia in T2DM patients treated with metformin [45]. However, caution is needed when analyzing such indirect/comparative results and a head-to-head comparative trial between dulaglutide, albiglutide and exenatide extended-release would be necessary to draw definite conclusion. Nevertheless, one advantage of dulaglutide over some other GLP-1 RAs is that the drug is not eliminated via the kidneys and thus may be used without any dose adjustment in patients with mild to moderate renal impairment. [48]

GLP-1 RAs are expensive agents for T2DM therapy. An important question that may arise in elinical practice is which patients will best benefit from a therapy with GLP-1 RA, in general, and dulaglutide, in particular? In United Kingdom, NICE (National Institute for Health and Care Excellence) recommends the use of GLP-1 RAs in patients with body mass index $\geq 35 \mathrm{~kg} / \mathrm{m}^{2}$ to profit of the weight reduction offered by this class of agents. [49] Nevertheless, HbA1c reduction obtained with GLP-1 RAs is generally similar in obese and non-obese patients. [7] In France, the Haute Autorité de Santé (HAS) recommends the use of injectable agents such as GLP-1 RAs if HbA1c level is $\geq 1 \%$ above the target with oral therapies because injectable medications have proven to be more efficacious to reduce HbAlc levels compared to oral drugs in many comparative clinical trials (but at the expense of a 
higher cost). [50] Another possibility to optimize the therapeutic strategy is to detect as early as possible potential good responders to GLP-1 RAs. Clinical markers of low $\beta$-cell function have been shown to be associated with reduced glycemic response to GLP-1 RA therapy both in a Caucasian population from UK [51] and in Asian patients, [52] with lower durability of the glucose-lowering effect as noticed with liraglutide therapy. [53] A post-hoc analysis of AWARD trials demonstrated that early ( 2 weeks) fasting glucose measurements can prediet later glycemic response to once weekly dulaglutide. [54]

Finally, it should be noticed that current available data don't provide any information about the clinical efficacy of dulaglutide on hard outcomes, especially macrovascular and microvascular complications. Long-term (> 2 years) safety of dulaglutide remains largely unknown. We have to wait for the results of the ongoing long-term prospective outcome study (REWIND) to benefit from this important information from a clinical point of view (see next section Five-year view).

\section{Five-year view}

One may speculate that the place of GLP-1 RAs for the management of T2DM will continue to increase in the next few years. The current limitations are the higher cost, the necessity of subcutaneous injection and the gastrointestinal side effects. [3] The possibility to inject a GLP-1 RA once weekly instead of once daily would reduce the reluctance of patients to accept injections and possibly improve satisfaction and compliance, especially if efficacy is maintained and tolerance is improved. [11, 55] However, other modes of administration of GLP-1 RAs are currently in development. For instance, continuous subcutaneous delivery of exenatide via ITCA 650 leads to sustained glycemic control and weight loss for 48 weeks in metformin-treated subjects with T2DM. [56] Whether such or other modes of administration may replace weekly injections of GLP-1 RAs in the future remains an open question.

There are still questions remaining about long-term safety and efficacy of GLP-1 RAs. Regarding safety, the concern about a possible increased risk of acute pancreatitis and pancreatic cancer with incretin-based therapies seems less prominent now than a couple of years ago, even if post-marketing surveillance is still recommended. [57] The evaluation of this risk is part of the Risk Evaluation and Mitigation Strategy program for dulaglutide. Regarding clinical efficacy, no data are available yet demonstrating a positive effects of GLP1 RAs on diabetic vascular complications, both microangiopathy and macroangiopathy. The 
effects of GLP-1 RAs on major cardiovascular events are currently being investigated. [58] [59] As firm evidence that in T2DM cardiovascular disease can be reversed or prevented by improving glycemic control is still incomplete, [60] large, long-term clinical trials in patients using modern treatment strategies, i.e. drug combinations designed to maximize $\mathrm{HbA1c}$ reduction while minimizing hypoglycemia and excessive weight gain are of major interest. [61] The purpose of REWIND (ClinicalTrials.gov Identifier: NCT01394952) is to assess whether dulaglutide $1.5 \mathrm{mg}$ once weekly can reduce major cardiovascular events and other serious outcomes in persons with T2DM, when added to their anti-hyperglycemic regimen. [62] The primary outcome measure is time from randomization to first occurrence of cardiovascular death, non-fatal myocardial infarction, or non-fatal stroke (a composite cardiovascular outcome) and the estimated average duration of follow up is about 6.5 years. The estimated enrolment is about 9.600 T2DM patients with age $\geq 50$ years with established clinical vascular disease, or age $\geq 55$ years and subclinical vascular disease or age $\geq 60$ years and at least two cardiovascular risk factors. Completion of the study is not expected before 2019. It would be interesting at that time to compare the results of the different cardiovascular outcome trials performed with DPP-4 inhibitors, GLP-1 RAs or SGLT2 (sodium glucose cotransporters type 2) inhibitors. [58,61] Such comparative analysis might help to guide the choice of the clinician in the future for the management of hyperglycemia in T2DM. [63]

A review of dulaglutide at ClinicalTrials.gov reveals several ongoing trials, including studies comparing dulaglutide to placebo in patients already receiving sulfonylurea therapy (NCT01769378), glimepiride (NCT01644500), and once-daily basal glargine insulin (NCT01648582). The primary outcome for each of these studies is change in HbA1c at 24-26 weeks. The future of GLP-1 RAs offers broader treatment options for T2DM as well as potential in other treatment areas. [64] Besides the combination with basal insulin in T2DM patients, [65, 66] GLP-1 RAs are currently being studied in new clinical areas, [64] as adjunctive therapy to insulin in patients with type 1 diabetes, [67] and for weight loss in obese non-diabetic individuals (especially liraglutide, which received recent approval as an antiobesity agent). [68] Up to now, dulaglutide has not been specifically investigated in these alternative indications other than the management of T2DM. Other exciting developments with GLP-1 RAs are ongoing with alternative modes of administration, either continuous subcutaneous delivery or even oral administration (semaglutide). 


\section{Key issues}

- Incretin-based therapies, including GLP-1 receptor agonists, occupy a growing place in the management of T2DM

- Dulaglutide is a new human GLP-1 receptor agonist designed to be injected once weekly at a dose of $0.75-1.50 \mathrm{mg}$ in Caucasian patients (lower doses in Japanese patients)

- Dulaglutide reduces both fasting and postprandial glucose, mainly by stimulating insulin secretion and reducing glucagon secretion in a glucose-dependent manner, thus with a low risk of hypoglycemia

- Dulaglutide has been evaluated in the AWARD program, mainly in Caucasian people, and the efficacy and safety results were confirmed in several trials performed in Japanese patients

- Dulaglutide has proven its efficacy in reducing HbAlc in T2DM patients treated with diet alone, metformin, dual oral therapy (metformin plus sulfonylurea or metformin plus pioglitazone) and even lispro insulin

- Dulaglutide $1.5 \mathrm{mg}$ once weekly is more potent than metformin, exenatide, insulin glargine (if not forced titrated to target), and as effective as liraglutide $1.8 \mathrm{mg}$ once daily

- Dulaglutide has the same tolerance and safety profile as other GLP-1 RAs, with transient gastrointestinal disturbances as most frequent adverse events

- Dulaglutide is currently evaluated in a large, prospective, cardiovascular outcome trial (REWIND) whose results are not awaited before 2019

\section{Financial and competing interests disclosure}

A.J. Scheen has received lecture/advisor/investigator fees from AstraZeneca/BMS, Boehringer Ingelheim, Eli Lilly, GlaxoSmithKline, Janssen, Merck Sharp \& Dohme, Novartis, NovoNordisk, Sanofi-Aventis and Takeda. The authors have no other relevant affiliations or financial involvement with any organization or entity with a financial interest in or financial conflict with the subject matter or materials discussed in the manuscript apart from those disclosed 
Figure 1 : A) Schematic structure of dulaglutide, a homodimer that consists of two identical polypeptide chains comprising a human glucagon-like peptide-1 (GLP-1) analog, a linker and a modified IgG4 Fc domain. B) Sequence of amino acids of dulaglutide (amino acids in position 8, 22 and 36 differ from human GLP-1). Adapted from reference with permission [13].

A)
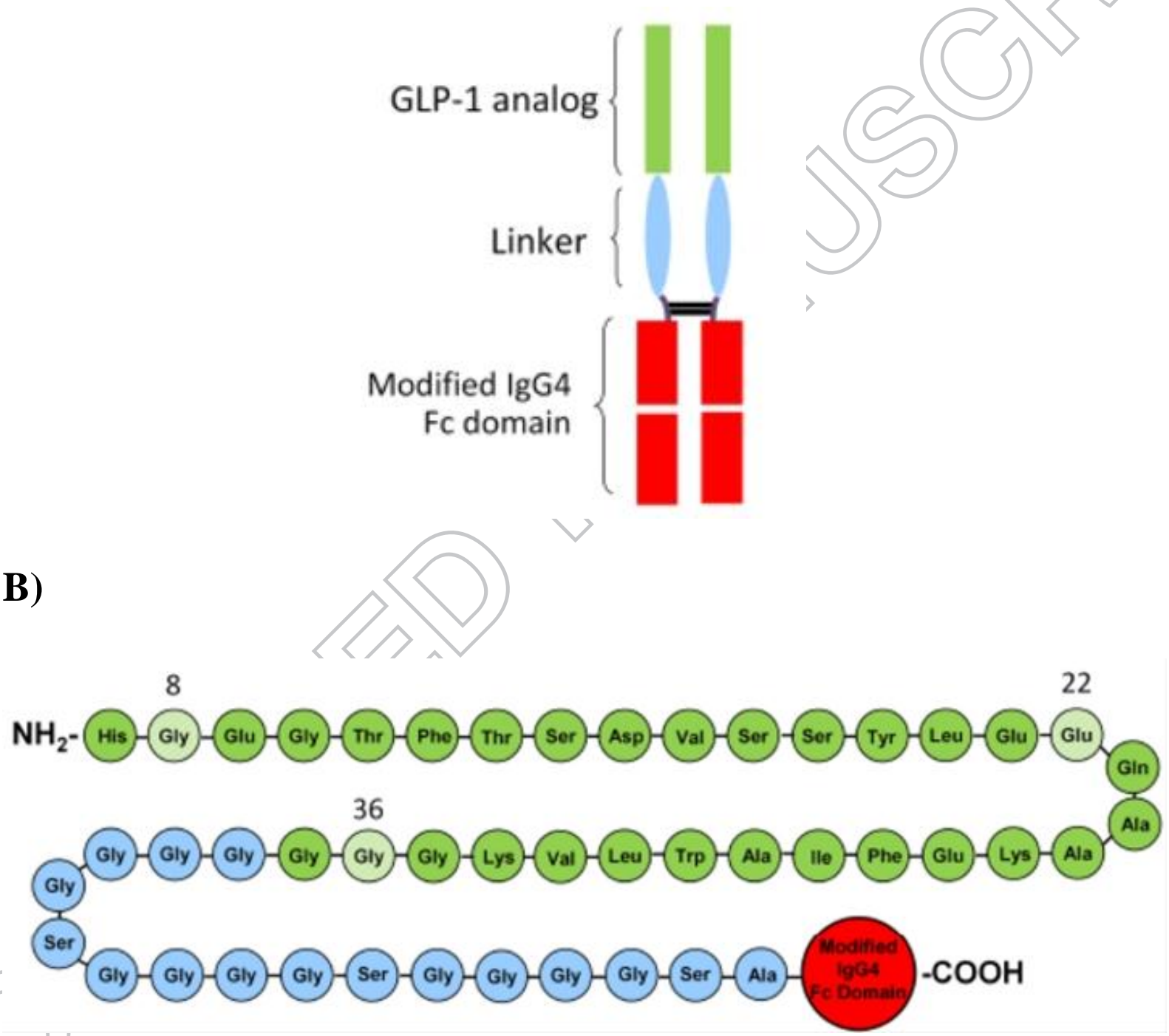
Table 1 : Effects on HbA1c and body weight of dulaglutide in the clinical trials of the AWARD program in patients with type 2 diabetes.

\begin{tabular}{|c|c|c|c|c|c|c|c|c|c|c|c|c|}
\hline $\begin{array}{l}\text { Reference } \\
\text { (trial name) }\end{array}$ & $\begin{array}{l}\text { Background } \\
\text { therapy }\end{array}$ & $\begin{array}{c}\text { Added } \\
\text { treatment }\end{array}$ & n & $\begin{array}{c}\text { Follow } \\
\text { up } \\
\text { Weeks }\end{array}$ & $\begin{array}{l}\text { Baseline } \\
\text { HbA1c \% } \\
\text { Mean } \\
\text { (SD) }\end{array}$ & $\begin{array}{c}\Delta \text { HbA1c } \\
\text { vs baseline } \\
\% \\
\text { Mean (SE) }\end{array}$ & $\begin{array}{c}\Delta \text { HbA1c } \\
\text { Treatment } \\
\text { difference } \\
\% \\
\text { Mean }(95 \% \\
\text { CI) }\end{array}$ & $\begin{array}{l}\text { P value } \\
(\text { vs } \\
\text { compa- } \\
\text { rator })\end{array}$ & $\begin{array}{l}\text { Baseline } \\
\text { body } \\
\text { weight kg } \\
\text { Mean } \\
\text { (SD) }\end{array}$ & $\begin{array}{c}\Delta \text { body } \\
\text { weight vs } \\
\text { baseline } \\
\text { kg } \\
\text { Mean (SE) }\end{array}$ & $\begin{array}{c}\Delta \text { body } \\
\text { weight } \\
\text { Treatment } \\
\text { difference } \\
\text { kg } \\
\text { Mean } \\
(95 \% \mathrm{CI})\end{array}$ & $\begin{array}{l}\text { P value } \\
\text { (vs } \\
\text { compa- } \\
\text { rator) }\end{array}$ \\
\hline \multirow{4}{*}{$\begin{array}{l}\text { Wysham et al } 2014 \\
\text { [29] } \\
\text { (AWARD-1) }\end{array}$} & \multirow{4}{*}{$\begin{array}{c}\text { Metformin + } \\
\text { pioglitazone }\end{array}$} & $\begin{array}{c}\text { Dulaglutide } \\
0.75 \mathrm{mg} \mathrm{OW}\end{array}$ & 280 & \multirow{4}{*}{$\begin{array}{c}26 \\
\text { (Final } \\
52)\end{array}$} & $8.1(1.2)$ & $-1.30(0.06)$ & $\begin{array}{c}-0.84(-1.01 \\
\text { to }-0.67) \mathrm{vs} \\
\text { placebo } \\
-0.31(-0.44 \\
\text { to }-0.18) \mathrm{vs} \\
\text { exenatide }\end{array}$ & $\begin{array}{c}<0.001 \\
\text { vs } \\
\text { placebo } \\
\text { and } \\
\text { exenatide }\end{array}$ & $96(21)$ & $\begin{array}{c}0.20 \\
(0.29)\end{array}$ & $\begin{array}{c}1.04(\mathrm{NA}) \\
\text { vs placebo } \\
1.27 \text { (NA) } \\
\text { vs } \\
\text { exenatide }\end{array}$ & $\begin{array}{l}=0.010 \mathrm{vs} \\
\text { placebo } \\
<0.001 \mathrm{vs} \\
\text { exenatide }\end{array}$ \\
\hline & & $\begin{array}{l}\text { Dulaglutide } \\
1.5 \mathrm{mg} \mathrm{OW}\end{array}$ & 279 & & & & $\begin{array}{c}-1.05(-1.22 \\
\text { to }-0.88) \text { vs } \\
\text { placebo } \\
-0.52(-0.66 \\
\text { to }-0.39) \text { vs } \\
\text { exenatide }\end{array}$ & $\begin{array}{c}<0.001 \\
\text { vs } \\
\text { placebo } \\
\text { and } \\
\text { exenatide }\end{array}$ & $96(20)$ & $\begin{array}{l}-1.30 \\
(0.29)\end{array}$ & $\begin{array}{c}-2.54 \text { (NA) } \\
\text { vs placebo } \\
-0.24 \text { (NA) } \\
\text { vs } \\
\text { exenatide }\end{array}$ & $\begin{array}{c}<0.001 \mathrm{vs} \\
\text { placebo } \\
\text { NS vs } \\
\text { exenatide }\end{array}$ \\
\hline & & $\begin{array}{c}\text { Exenatide } 10 \\
\mu \mathrm{g} \text { BID }\end{array}$ & 276 & & & $-0.99(0.06)$ & & & 97 (19) & $\begin{array}{l}-1.07 \\
(0.29)\end{array}$ & & \\
\hline & & Placebo & 141 & & (1.3) & $-0.46(0.08)$ & & & 94 (19) & $1.24(0.37)$ & & \\
\hline \multirow{3}{*}{$\begin{array}{l}\text { Giorgino et al } 2014 \\
\text { (AWARD-2) }\end{array}$} & \multirow{3}{*}{$\begin{array}{l}\text { Metformin + } \\
\text { glimepiride }\end{array}$} & $\begin{array}{c}\text { Dulaglutide } \\
0.75 \mathrm{mg} \mathrm{OW}\end{array}$ & & \multirow{3}{*}{$\begin{array}{l}\text { (Final } \\
78)\end{array}$} & $8.1(1.0)$ & $-0.76(0.06)$ & $\begin{array}{c}-0.13(-0.29 \\
\text { to } 0.02)\end{array}$ & NS & $86(18)$ & $\begin{array}{l}-1.33 \\
(0.34)\end{array}$ & NA & $<0.001$ \\
\hline & & $\begin{array}{l}\text { Dulaglutide } \\
1.5 \mathrm{mg} \mathrm{OW}\end{array}$ & 273 & & $8.2(1.0)$ & $-1.08(0.06)$ & $\begin{array}{c}-0.45(-0.60 \\
\text { to }-0.29)\end{array}$ & $<0.001$ & $85(18)$ & $\begin{array}{l}-1.87 \\
(0.24) \\
\end{array}$ & NA & $<0.001$ \\
\hline & & $\begin{array}{l}\text { Insulin } \\
\text { Glargine }\end{array}$ & 262 & & $8.1(1.0)$ & $-0.63(0.06)$ & & & $88(20)$ & $\begin{array}{l}+1.44 \\
(0.24)\end{array}$ & & \\
\hline \multirow{2}{*}{$\begin{array}{l}\text { Umpierrez et al } 2014 \\
\text { [24] } \\
\text { (AWARD-3) }\end{array}$} & \multirow{2}{*}{$\begin{array}{l}\text { No } \\
\text { antidiabetic } \\
\text { medication }\end{array}$} & $\begin{array}{l}\text { Dulaglutide } \\
0.75 \mathrm{mg} \text { OW }\end{array}$ & 270 & \multirow{2}{*}{$\begin{array}{c}26 \\
\text { (Final } \\
52)\end{array}$} & $7.6(0.9)$ & $-0.71(0.06)$ & -0.15 (NA) & $=0.02$ & $93(19)$ & $\begin{array}{l}-1.36 \\
(0.24)\end{array}$ & NA & $=0.003$ \\
\hline & & $\begin{array}{l}\text { Dulaglutide } \\
1.5 \mathrm{mg} \mathrm{OW}\end{array}$ & 269 & & $7.6(0.9)$ & $-0.78(0.06)$ & $\begin{array}{c}-0.22(-0.36 \\
\text { to }-0.08)\end{array}$ & $=0.002$ & 92 (19) & $\begin{array}{l}-2.29 \\
(0.24)\end{array}$ & NA & NS \\
\hline
\end{tabular}




\begin{tabular}{|c|c|c|c|c|c|c|c|c|c|c|c|c|}
\hline & & Metformin & 268 & & $7.6(0.8)$ & $-0.56(0.06)$ & & & $92(19)$ & $\begin{array}{l}-2.22 \\
(0.24)\end{array}$ & & \\
\hline \multirow{3}{*}{$\begin{array}{l}\text { Blonde et al } 2015 \\
\text { [30] (AWARD-4) }\end{array}$} & \multirow{3}{*}{$\begin{array}{c}\text { Insulin } \\
\text { lispro } \pm \\
\text { metformin }\end{array}$} & $\begin{array}{l}\text { Dulaglutide } \\
0.75 \mathrm{mg} \mathrm{OW}\end{array}$ & 293 & \multirow{3}{*}{$\begin{array}{c}26 \\
\text { (Final } \\
52)\end{array}$} & $8.40(1.03)$ & $\begin{array}{c}-1.59(0.07) \\
(*)\end{array}$ & $\begin{array}{c}-0.17(-0.33 \\
\text { to }-0.02)\end{array}$ & .0 & $91.7(18.0)$ & $\begin{array}{c}+0.18 \\
(0.27)(*)\end{array}$ & NA & $<0.0001$ \\
\hline & & $\begin{array}{l}\text { Dulaglutide } \\
1.5 \mathrm{mg} \mathrm{OW}\end{array}$ & 295 & & $8.46(1.08)$ & $\begin{array}{c}-1.64(0.07) \\
(*)\end{array}$ & $\begin{array}{c}-0.22(-0.38 \\
\text { to }-0.07)\end{array}$ & & $91.0(18.2)$ & $\begin{array}{c}-0.87 \\
(0.27)(*)\end{array}$ & NA & $<0.0001$ \\
\hline & & $\begin{array}{l}\text { Insulin } \\
\text { glargine }\end{array}$ & 296 & & $8.53(1.03)$ & $\begin{array}{c}-1.41(0.07) \\
(*)\end{array}$ & & & $90.8(18.9)$ & $\begin{array}{c}+2.33 \\
(0.21)(*) \\
\end{array}$ & & \\
\hline \multirow{4}{*}{$\begin{array}{l}\text { Nauck et al } 2014 \\
{[25]} \\
\text { (AWARD-5) }\end{array}$} & \multirow{4}{*}{$\begin{array}{l}\text { Metformin } \\
\geq 1500 \mathrm{mg}\end{array}$} & $\begin{array}{l}\text { Dulaglutide } \\
0.75 \mathrm{mg} \mathrm{OW}\end{array}$ & 302 & \multirow{4}{*}{$\begin{array}{c}52 \\
\text { (Final } \\
104)\end{array}$} & $8.2(1.1)$ & $-0.87(0.06)$ & $\begin{array}{r}-0.47(\mathrm{~N} \\
\text { vs sitagli }\end{array}$ & .001 & 86 (18) & $\begin{array}{l}-2.60 \\
(0.23)\end{array}$ & $\begin{array}{c}-1.07 \text { (NA) } \\
\text { vs } \\
\text { sitagliptin } \\
\end{array}$ & $\begin{array}{l}<0.001 \mathrm{vs} \\
\text { sitagliptin }\end{array}$ \\
\hline & & $\begin{array}{l}\text { Dulaglutide } \\
1.5 \mathrm{mg} \mathrm{OW}\end{array}$ & 304 & & $8.1(1.1)$ & $-1.10(0$ & gliptin & $<0.001$ & 87 (17) & $\begin{array}{l}-3.03 \\
(0.22)\end{array}$ & $\begin{array}{c}-1.50 \text { (NA) } \\
\text { vs } \\
\text { sitagliptin }\end{array}$ & $\begin{array}{l}<0.001 \mathrm{vs} \\
\text { sitagliptin }\end{array}$ \\
\hline & & $\begin{array}{l}\text { Sitagliptin } \\
100 \mathrm{mg} \\
\end{array}$ & 315 & & $8.1(1.1)$ & & & & $86(17)$ & $\begin{array}{l}-1.53 \\
(0.22) \\
\end{array}$ & & \\
\hline & & Placebo $(* *)$ & 177 & & $8.1(1.1)$ & $0.03(0.07)$ & & & 87 (17) & NA & & \\
\hline \multirow{2}{*}{$\begin{array}{l}\text { Dungan et al } 2014 \\
\text { [27] } \\
\text { (AWARD-6) }\end{array}$} & \multirow{2}{*}{$\begin{array}{l}\text { Metformin } \\
\geq 1500 \mathrm{mg}\end{array}$} & $\begin{array}{l}\text { Dulaglutide } \\
1.5 \mathrm{mg} \mathrm{OW}\end{array}$ & 299 & \multirow{2}{*}{26} & $8.1(0.8)$ & $-1.42(0.05)$ & \multirow{2}{*}{$\begin{array}{c}-0.06 \\
(-0.19 \text { to } \\
0.07)\end{array}$} & \multirow{2}{*}{ NS } & $93.8(18.2)$ & $\begin{array}{l}-2.90 \\
(0.22)\end{array}$ & \multirow{2}{*}{$\begin{array}{l}0.71(0.17 \\
\text { to } 1.26)\end{array}$} & \multirow{2}{*}{0.010} \\
\hline & & $\begin{array}{l}\text { Liraglutide } \\
1.8 \mathrm{mg} \text { OD }\end{array}$ & 300 & & $8.1(0.8)$ & $-1.36(0.05)$ & & & $94.4(19.0)$ & $\begin{array}{l}-3.61 \\
(0.22)\end{array}$ & & \\
\hline
\end{tabular}

$\Delta$ : change versus baseline. SD : standard deviation. SE : standard error. OD : once-daily. OW : once-weekly. CI : confidence interval. NA : not available. NS : not significant.

(*) SE not given in the paper and calculated from confidence intervals

(**) Placebo arm limited to the first 26 weeks (results at 26 weeks only given for information)

Extension results (not shown) confirmed data obtained after the first period of evaluation (primary analysis). 
Table 2 : Effects on HbA1c and body weight of dulaglutide in clinical trials outside the AWARD program in Caucasian and Japanese patients with type 2 diabetes..

\begin{tabular}{|c|c|c|c|c|c|c|c|c|c|c|c|c|}
\hline Reference & $\begin{array}{c}\text { Background } \\
\text { therapy }\end{array}$ & $\begin{array}{l}\text { Added } \\
\text { treatment }\end{array}$ & $\mathbf{n}$ & $\begin{array}{l}\text { Follow } \\
\text { up } \\
\text { Weeks }\end{array}$ & $\begin{array}{l}\text { Baseline } \\
\text { HbA1c \% } \\
\text { Mean } \\
\text { (SD) }\end{array}$ & $\begin{array}{c}\Delta \text { HbA1c } \\
\text { vs baseline } \\
\% \\
\text { Mean (SE) }\end{array}$ & $\begin{array}{c}\Delta \text { HbA1c } \\
\text { Treatment } \\
\text { difference } \\
\% \\
\text { Mean }(95 \%\end{array}$ & $\begin{array}{c}\text { P value } \\
\text { (vs } \\
\text { compa- } \\
\text { rator) }\end{array}$ & $\begin{array}{l}\text { Baseline } \\
\text { body } \\
\text { weight kg } \\
\text { Mean } \\
\text { (SD) }\end{array}$ & $\begin{array}{c}\Delta \text { body } \\
\text { weight vs } \\
\text { baseline } \\
\text { kg } \\
\text { Mean (SE) }\end{array}$ & $\begin{array}{c}\Delta \text { body } \\
\text { weight } \\
\text { Treatment } \\
\text { difference } \\
\text { kg } \\
\text { Mean } \\
(95 \% \mathrm{CI})\end{array}$ & $\begin{array}{l}\text { P value } \\
\text { (vs } \\
\text { compa- } \\
\text { rator) }\end{array}$ \\
\hline \multicolumn{13}{|c|}{ Caucasian T2DM patients } \\
\hline \multirow{4}{*}{$\begin{array}{l}\text { Grunberger et al } \\
2012 \text { [22] }\end{array}$} & \multirow{4}{*}{$\begin{array}{l}\text { No } \\
\text { antidiabetic } \\
\text { medication }\end{array}$} & $\begin{array}{l}\text { Dulaglutide } \\
0.5 \mathrm{mg} \text { OW }\end{array}$ & 34 & \multirow{4}{*}{12} & $7.2(0.6)$ & NA & $\begin{array}{l}0.89(-1.21 \\
\text { to }-0.57)\end{array}$ & $<0.001$ & $90.2(21.3)$ & $-0.3(0.4)$ & NA & NS \\
\hline & & $\begin{array}{l}\text { Dulaglutide } \\
1.0 \mathrm{mg} \mathrm{OW}\end{array}$ & 34 & & $7.3(0.7)$ & & $\begin{array}{c}-1.04(-1.36 \\
\text { to }-0.72)\end{array}$ & $<0.001$ & $86.9(17.0)$ & $-1.1(0.4)$ & NA & NS \\
\hline & & $\begin{array}{l}\text { Dulaglutide } \\
1.5 \mathrm{mg} \mathrm{OW}\end{array}$ & 29 & & $7.3(0.4)$ & & $\begin{array}{c}-1.04(-1.39 \\
\text { to }-0.70)\end{array}$ & $<0.001$ & $85.8(18.6)$ & $-1.5(0.5)$ & NA & NS $(*)$ \\
\hline & & Placebo & 32 & & $7.4(0.6)$ & $0.01(0.13)$ & & & $90.9(18.9)$ & $-1.4(0.5)$ & & \\
\hline \multirow{4}{*}{$\begin{array}{l}\text { Umpierrez et al } \\
2011 \text { [26] }\end{array}$} & \multirow{4}{*}{$\begin{array}{l}\text { Two oral } \\
\text { antidiabetic } \\
\text { agents }\end{array}$} & $\begin{array}{c}\text { Dulaglutide } \\
0.5->1.0 \\
\text { mg OW }\end{array}$ & 66 & & $0.9)$ & $-1.38(0.12)$ & NA & $<0.001$ & $94.8(17)$ & $\begin{array}{l}-1.44 \\
(0.39)\end{array}$ & NA & $<0.05$ \\
\hline & & $\begin{array}{c}\text { Dulaglutide } \\
1.0->1.0 \\
\text { mg OW }\end{array}$ & & & $8.25(1.0)$ & $-1.32(0.12)$ & NA & $<0.001$ & $96.7(17)$ & $\begin{array}{l}-1.34 \\
(0.39)\end{array}$ & NA & $<0.05$ \\
\hline & & $\begin{array}{c}\text { Dulaglutide } \\
1.0->2.0 \\
\text { mg OW }\end{array}$ & & & $8.43(1.0)$ & $-1.59(0.12)$ & NA & $<0.001$ & $98.6(18.4)$ & $\begin{array}{l}-2.55 \\
(0.40)\end{array}$ & NA & $<0.001$ \\
\hline & & Placebo & 66 & & $8.05(0.8)$ & $-0.25(0.12)$ & & & $94.7(15)$ & $\begin{array}{l}-0.12 \\
(0.39)\end{array}$ & & \\
\hline \multicolumn{13}{|c|}{ Japanese T2DM patients } \\
\hline \multirow{2}{*}{$\begin{array}{l}\text { Terauchi al } \\
2014 \text { [23] }\end{array}$} & \multirow{2}{*}{$\begin{array}{c}\text { No } \\
\text { antidiabetic } \\
\text { medication }\end{array}$} & $\begin{array}{l}\text { Dulaglutide } \\
0.25 \mathrm{mg} \mathrm{OW}\end{array}$ & 36 & \multirow{2}{*}{12} & $8.1(0.7)$ & $-0.90(0.09)$ & $\begin{array}{c}-0.72(-0.95 \\
\text { to }-0.48)\end{array}$ & $<0.01$ & $74.0(14.5)$ & $+0.4(0.3)$ & $\begin{array}{c}1.3(0.4 \text { to } \\
2.1)\end{array}$ & 0.005 \\
\hline & & $\begin{array}{l}\text { Dulaglutide } \\
0.50 \mathrm{mg} \mathrm{OW}\end{array}$ & 37 & & $8.0(0.7)$ & $-1.15(0.09)$ & $\begin{array}{c}-0.97(-1.20 \\
\text { to }-0.73)\end{array}$ & $<0.01$ & $72.1(12.8)$ & $-0.4(0.3)$ & $\begin{array}{c}0.5(-0.4 \text { to } \\
1.3)\end{array}$ & NS \\
\hline
\end{tabular}




\begin{tabular}{|c|c|c|c|c|c|c|c|c|c|c|c|c|}
\hline & & $\begin{array}{c}\text { Dulaglutide } \\
0.75 \mathrm{mg} \mathrm{OW} \\
\end{array}$ & 35 & & $8.0(0.6)$ & $-1.35(0.09)$ & $\begin{array}{c}-1.17(-1.41 \\
\text { to }-0.93)\end{array}$ & $<0.01$ & $75.8(10.8)$ & $-0.6(0.3)$ & $\begin{array}{c}0.3(-0.6 \text { to } \\
1.1) \\
\end{array}$ & NS \\
\hline & & Placebo & 37 & & $8.0(0.6)$ & $-0.18(0.09)$ & & & $74.6(13.6)$ & $-0.8(03)$ & & \\
\hline \multirow{3}{*}{$\begin{array}{l}\text { Miyagawa et al } \\
2015 \text { [33] }\end{array}$} & \multirow{3}{*}{$\begin{array}{c}\text { No } \\
\text { antidiabetic } \\
\text { medication }\end{array}$} & $\begin{array}{c}\text { Dulaglutide } \\
0.75 \mathrm{mg} \mathrm{OW}\end{array}$ & 280 & \multirow{3}{*}{$\begin{array}{c}26 \\
\text { (Final } \\
52)\end{array}$} & $8.15(0.77)$ & $-1.43(0.05)$ & \multirow{3}{*}{$\begin{array}{c}-1.57(-1.79 \\
\text { to }-1.35) \mathrm{vs} \\
\text { placebo }\end{array}$} & & $71.3(12.5)$ & -0.02 (NA) & \multirow{3}{*}{$\begin{array}{c}\text { NA vs } \\
\text { placebo } \\
\text { NA vs } \\
\text { liraglutide }\end{array}$} & \multirow{3}{*}{$\begin{array}{c}\text { NS } \\
\text { vs placebo } \\
\text { NS vs } \\
\text { liraglutide }\end{array}$} \\
\hline & & Placebo & 137 & & $8.08(0.89)$ & $0.14(0.10)$ & & & $70.2(12.5)$ & -0.36 (NA) & & \\
\hline & & $\begin{array}{c}\text { Liraglutide } \\
0.3->0.9 \mathrm{mg} \\
\text { OD }\end{array}$ & 70 & & $8.20(0.83)$ & $-1.33(0.07)$ & & $\begin{array}{c}\text { liraglutid } \\
\mathrm{e}\end{array}$ & $69.3(11.6)$ & -0.63 (NA) & & \\
\hline \multirow{2}{*}{$\begin{array}{l}\text { Araki et al } \\
2015 \text { [34] }\end{array}$} & \multirow{2}{*}{$\begin{array}{l}\text { Metformin } \pm \\
\text { sulfonylurea }\end{array}$} & $\begin{array}{l}\text { Dulaglutide } \\
0.75 \mathrm{mg} \mathrm{OW}\end{array}$ & 181 & \multirow[t]{2}{*}{26} & $8.06(0.82)$ & $-1.44(0.05)$ & to -0.41$)$ & $<0.001$ & $71.0(13.7)$ & $-0.48(017)$ & $\begin{array}{c}-1.42 \\
(-1.89 \text { to - } \\
0.94) \\
\end{array}$ & $<0.001$ \\
\hline & & Glargine & 180 & & 7.99 (087) & $-0.90(0.05)$ & & & $71.1(13.8)$ & $0.94(0.17)$ & & \\
\hline
\end{tabular}

$\Delta$ : change versus baseline. SD : standard deviation. SE : standard error. OD : once-daily. OW : once-weekly. CI : confidence interval. NA : not available. NS : not significant.

(*) Dose-dependent weight loss across the three dulaglutide groups. 
Table 3 : Effects on HbA1c and body weight in head-to-head trials of $\geq 24$ weeks duration comparing a once-weekly glucagon-like peptide-1 receptor agonist (GLP-1 RA) with once-daily liraglutide $1.8 \mathrm{mg}$ (used as comparator) in patients with type 2 diabetes not well controlled with metformin.

\begin{tabular}{|c|c|c|c|c|c|c|c|c|c|c|c|c|}
\hline $\begin{array}{l}\text { Reference } \\
\text { (trial name) }\end{array}$ & GLP-1 RA & n & $\begin{array}{l}\text { Follow } \\
\text { up } \\
\text { Weeks }\end{array}$ & $\begin{array}{c}\text { Baseline } \\
\text { HbA1c \% } \\
\text { Mean } \\
\text { (SD) }\end{array}$ & $\begin{array}{c}\Delta \text { HbA1c } \\
\text { vs baseline } \\
\% \\
\text { Mean (SE) }\end{array}$ & $\begin{array}{c}\Delta \text { HbA1c } \\
\text { Treatment } \\
\text { difference } \\
\% \\
\text { Mean (95\% } \\
\text { CI) }\end{array}$ & $\begin{array}{c}\text { P value } \\
\text { (vs } \\
\text { compa- } \\
\text { rator) }\end{array}$ & $\begin{array}{l}\text { HbAlc } \\
\text { reduction } \\
\text { Non-infe- } \\
\text { riority } \\
\text { margin } \\
(\%)\end{array}$ & $\begin{array}{c}\text { Baseline } \\
\text { body } \\
\text { weight kg } \\
\text { Mean } \\
\text { (SD) }\end{array}$ & $\begin{array}{c}\Delta \text { body } \\
\text { weight vs } \\
\text { baseline } \\
\text { kg } \\
\text { Mean (SE) }\end{array}$ & $\begin{array}{c}\Delta \text { body } \\
\text { weight } \\
\text { Treatment } \\
\text { difference } \\
\text { kg } \\
\text { Mean } \\
(95 \% \text { CI })\end{array}$ & $\begin{array}{l}\text { P value } \\
\text { (vs } \\
\text { compa- } \\
\text { rator) }\end{array}$ \\
\hline \multirow{2}{*}{$\begin{array}{l}\text { Buse et al } 2013 \text { [46] } \\
\text { (DURATION-6) }\end{array}$} & $\begin{array}{l}\text { Exenatide } \\
2 \mathrm{mg} \mathrm{OW}\end{array}$ & 461 & 26 & $8.5(1.0)$ & $-1.28(0.05)$ & \multirow{2}{*}{$\begin{array}{c}0.21 \\
0.08 \text { to } \\
0.33)\end{array}$} & \multirow{2}{*}{0.02} & \multirow{2}{*}{$\begin{array}{c}0.25 \\
\text { (not met : } \\
\mathrm{p}=\mathrm{NA} \text { ) }\end{array}$} & $90.9(19.5)$ & $\begin{array}{l}-2.68 \\
(0.18)\end{array}$ & \multirow{2}{*}{$\begin{array}{l}0.90(0.39 \\
\text { to } 1.40)\end{array}$} & \multirow{2}{*}{0.0005} \\
\hline & $\begin{array}{l}\text { Liraglutide } \\
1.8 \mathrm{mg} \text { OD }\end{array}$ & 450 & 26 & $8.4(1.0)$ & $-1.48(0.05)$ & & & & $91.1(19.1)$ & $\begin{array}{l}-3.57 \\
(0.18)\end{array}$ & & \\
\hline \multirow{2}{*}{$\begin{array}{l}\text { Pratley et al } 2014 \\
\text { [47] } \\
\text { (HARMONY-7) }\end{array}$} & $\begin{array}{l}\text { Albiglutide } \\
30 \mathrm{mg} \text { OW }\end{array}$ & 404 & 32 & $8.18(0.89)$ & $-0.78(0.0$ & \multirow{2}{*}{$\begin{array}{l}0.21 \\
0.08 \text { to } \\
0.34)\end{array}$} & \multirow{2}{*}{ NA } & \multirow{2}{*}{$\begin{array}{c}0.3 \\
\text { (not met : } \\
\mathrm{p}=0.086 \text { ) }\end{array}$} & 91.7 (21.2) & $\begin{array}{l}-0.64 \\
(0.18)\end{array}$ & \multirow{2}{*}{$\begin{array}{c}1.55 \\
(1.05 \text { to } \\
2.06\end{array}$} & \multirow{2}{*}{$<0.0001$} \\
\hline & $\begin{array}{l}\text { Liraglutide } \\
1.8 \mathrm{mg} \text { OD }\end{array}$ & 408 & 32 & $8.15(0.84)$ & $-0.99(0.05)$ & & & & $92.8(22.1)$ & $\begin{array}{l}-2.19 \\
(0.18)\end{array}$ & & \\
\hline \multirow{2}{*}{$\begin{array}{l}\text { Dungan et al } 2014 \\
\text { [27] } \\
\text { (AWARD-6) }\end{array}$} & $\begin{array}{l}\text { Dulaglutide } \\
1.5 \mathrm{mg} \mathrm{OW}\end{array}$ & 299 & 26 & $8.1(0.8)$ & $1.42(0.05)$ & \multirow{2}{*}{$\begin{array}{c}-0.06 \\
(-0.19 \text { to } \\
0.07)\end{array}$} & \multirow{2}{*}{ NS } & \multirow{2}{*}{$\begin{array}{c}0.4 \\
(\text { met : } \\
\mathrm{p}<0.0001)\end{array}$} & $93.8(18.2)$ & $\begin{array}{l}-2.90 \\
(0.22)\end{array}$ & \multirow{2}{*}{$\begin{array}{l}0.71(0.17 \\
\text { to } 1.26)\end{array}$} & \multirow{2}{*}{0.011} \\
\hline & $\begin{array}{l}\text { Liraglutide } \\
1.8 \mathrm{mg} \text { OD }\end{array}$ & 300 & 26 & $8.1(0.8)$ & $-1.36(0.05)$ & & & & $94.4(19.0)$ & $\begin{array}{l}-3.61 \\
(0.22)\end{array}$ & & \\
\hline \multirow{2}{*}{$\begin{array}{l}\text { Takamura et al } 2015 \\
\text { [35] }(*)\end{array}$} & $\begin{array}{c}\text { Dulaglutide } \\
0.75 \mathrm{OW}\end{array}$ & 280 & 52 & $8.2(0.8)$ & $-1.39(0.06)$ & \multirow{2}{*}{$\begin{array}{c}-.0 .20 \\
(-0.39 \text { to }- \\
0.01)\end{array}$} & \multirow{2}{*}{0.04} & \multirow{2}{*}{ NA } & $71.3(12.5)$ & -0.17 (NA) & \multirow{2}{*}{$\begin{array}{c}-0.03 \\
(-0.64 \text { to } \\
0.57)\end{array}$} & \multirow{2}{*}{ NS } \\
\hline & $\begin{array}{l}\text { Liraglutide } \\
0.9 \text { mg OD }\end{array}$ & 137 & & $8.1(0.9)$ & $-1.19(0.08)$ & & & & $70.2(12.5)$ & -0.13 (NA) & & \\
\hline
\end{tabular}

$\Delta$ : change versus baseline. SD : standard deviation. SE : standard error. OD : once-daily. OW : once-weekly. CI : confidence interval. NA : not available. NS : not significant.

(*) Japanese patients treated with diet or oral monotherapy (excluding glitazone) 


\section{References}

*- Papers of interest

**-Papers of particular interest

1. Scheen AJ, Van Gaal LF. Combating the dual burden : therapeutic targeting of common pathways in obesity and type 2 diabetes. The lancet Diabetes \& endocrinology 2014;2:911-22.

2. American Diabetes A. Standards of medical care in diabetes--2014. Diabetes Care 2014;37 Suppl 1:S14-80.

** 3. Inzucchi SE, Bergenstal RM, Buse JB, et al. Management of hyperglycemia in type 2 diabetes, 2015: a patient-centered approach: update to a position statement of the American Diabetes Association and the European Association for the Study of Diabetes. Diabetes Care 2015;38:140-9.

A guide to the management of hyperglycemia of T2DM, positioning GLP-1 receptor agonists as second-line and third-line therapies

4. Garber AJ, Abrahamson MJ, Barzilay JI, et al. AACE comprehensive diabetes management algorithm 2013. Endocr Pract 2013;19:327-36.

5. Scheen AJ. A review of gliptins for 2014. Exp Opin Pharmacother 2015;16:43-62.

6. Scheen AJ. Pharmacodynamics, efficacy and safety of sodium-glucose co-transporter type 2 (SGLT2) inhibitors for the treatment of type 2 diabetes mellitus. Drugs 2015;75:33-59.

7. Meier JJ. GLP-1 receptor agonists for individualized treatment of type 2 diabetes mellitus. Nat Rev Endocrinol 2012;8:728-42.

8. Purnell TS, Joy S, Little E, et al. Patient preferences for noninsulin diabetes medications: a systematic review. Diabetes Care 2014;37:2055-62.

9. Van Gaal L, Scheen A. Weight management in type 2 diabetes: current and emerging approaches to treatment. Diabetes Care 2015;38:1161-72.

10. Potts JE, Gray LJ, Brady EM, et al. The effect of glucagon-like peptide 1 receptor agonists on weight loss in type 2 diabetes: a systematic review and mixed treatment comparison meta-analysis. PLoS One 2015;10:e0126769.

11. Polonsky WH, Fisher L, Hessler D, et al. Patient perspectives on once-weekly medications for diabetes. Diabetes Obes Metab 2011;13:144-9.

12. Sanford M. Dulaglutide: first global approval. Drugs 2014;74:2097-103.

13. Kuritzky L, Umpierrez G, Ekoe JM, et al. Safety and efficacy of dulaglutide, a once weekly GLP - 1 receptor agonist, for the management of type 2 diabetes. Postgrad Med 2014;126:60-72.

14. Thompson AM, Trujillo JM. Dulaglutide: the newest GLP-1 receptor agonist for the management of type 2 diabetes. Ann Pharmacother 2015;49:351-9.

15. Edwards KL, Minze MG. Dulaglutide: an evidence-based review of its potential in the treatment of type 2 diabetes. Core Evidence 2015;10:11-21.

16. Glaesner W, Vick AM, Millican R, et al. Engineering and characterization of the longacting glucagon-like peptide-1 analogue LY2189265, an Fc fusion protein. Diabetes Metab Res Rev 2010;26:287-96.

17. Agency EM. Assessment report : Trulicity (dulaglutide). 2014 [cited published on line;doi; Available from: http://www.ema.europa.eu/docs/en_GB/document_library/EPAR__Public_assessment_report/human/002825/WC500179473.pdf 
18. Barrington P, Chien JY, Tibaldi F, et al. LY2189265, a long-acting glucagon-like peptide-1 analogue, showed a dose-dependent effect on insulin secretion in healthy subjects. Diabetes Obes Metab 2011;13:434-8.

19. Barrington P, Chien JY, Showalter HD, et al. A 5-week study of the pharmacokinetics and pharmacodynamics of LY2189265, a novel, long-acting glucagon-like peptide-1 analogue, in patients with type 2 diabetes. Diabetes Obes Metab 2011;13:426-33.

20. de la Pena A, Loghin C, Cui X, et al. Pharmacokinetics of once weekly dulaglutide in patients with type 2 diabetes mellitus. Diabetes 2014;63:A251, 981-P.

21. Agency EM. Trulicity : Summary of product characteristics, http://wwwemaeuropaeu/docs/en_GB/document_library/EPAR_-

_Product_Information/human/002825/WC500179470pdf 2015;published on line;doi.

22. Grunberger G, Chang A, Garcia Soria G, et al. Monotherapy with the once-weekly GLP-1 analogue dulaglutide for 12 weeks in patients with Type 2 diabetes: dose-dependent effects on glycaemic control in a randomized, double-blind, placebo-controlled study. Diabet Med 2012;29:1260-7.

23. Terauchi Y, Satoi Y, Takeuchi M, et al. Monotherapy with the once weekly GLP-1 receptor agonist dulaglutide for 12 weeks in Japanese patients with type 2 diabetes: dosedependent effects on glycaemic control in a randomised, double-blind, placebo-controlled study. Endocr J 2014;61:949-59.

* 24. Umpierrez G, Tofe Povedano S, Perez Manghi F, et al. Efficacy and safety of dulaglutide monotherapy versus metformin in type 2 diabetes in a randomized controlled trial (AWARD-3). Diabetes Care 2014;37:2168-76.

Study that demonstrated that dulaglutide (both 0.75 and $1.50 \mathrm{mg}$ once weekly) is superior to metformin in diet-treated patients with T2DM

* 25. Nauck M, Weinstock RS, Umpierrez GE, et al. Efficacy and safety of dulaglutide versus sitagliptin after 52 weeks in type 2 diabetes in a randomized controlled trial (AWARD5). Diabetes Care 2014;37:2149-58.

Study that demonstrated the superiority of dulaglutide (both 0.75 and $1.50 \mathrm{mg}$ once weekly) compared to sitagliptin $100 \mathrm{mg}$ in metformin-treated patients with T2DM

26. Umpierrez GE, Bleyins T, Rosenstock J, et al. The effects of LY2189265, a longacting glucagon-like peptide- 1 analogue, in a randomized, placebo-controlled, double-blind study of overweight/obese patients with type 2 diabetes: the EGO study. Diabetes Obes Metab 2011;13:418-25.

** 27. Dungan KM, Povedano ST, Forst T, et al. Once-weekly dulaglutide versus once-daily liraglutide in metformin-treated patients with type 2 diabetes (AWARD-6): a randomised, open-label, phase 3, non-inferiority trial. Lancet 2014;384:1349-57.

Study that demonstrated the non-inferiority of dulaglutide $1.5 \mathrm{mg}$ once weekly with liraglutide $1.8 \mathrm{mg}$ once daily in metformin-treated patients with T2DM

*28. Giorgino F, Benroubi M, Sun JH, et al. Efficacy and safety of once-weekly dulaglutide versus insulin glargine in patients with type 2 diabetes on metformin and glimepiride (AWARD-2). Diabetes Care 2015; Jun 18. pii: dc141625. [Epub ahead of print].

Study that demonstrated the superiority of dulaglutide $1.5 \mathrm{mg}$ once weekly compared to basal insulin glargine in patients on dual oral therapy.

* 29. Wysham C, Blevins T, Arakaki R, et al. Efficacy and safety of dulaglutide added onto pioglitazone and metformin versus exenatide in type 2 diabetes in a randomized controlled trial (AWARD-1). Diabetes Care 2014;37:2159-67.

Study that demonstrated the superiority of dulaglutide (both 0.75 and $1.50 \mathrm{mg}$ once weekly) compared to exenatide $10 \mu \mathrm{g}$ twice daily.

*30. Blonde L, Jendle J, Gross J, et al. Once-weekly dulaglutide versus bedtime insulin glargine, both in combination with prandial insulin lispro, in patients with type 2 diabetes 
(AWARD-4): a randomised, open-label, phase 3, non-inferiority study. Lancet 2015;385:2057-66.

Study that demonstrated the superiority of dulaglutide (both 0.75 and $1.50 \mathrm{mg}$ once weekly) compared to basal insulin glardine in patients treated with prandial insulin lispro.

31. Yabe D, Seino Y, Fukushima M, et al. beta cell dysfunction versus insulin resistance in the pathogenesis of type 2 diabetes in East Asians. Curr Diab Rep 2015;15:602.

32. Kim YG, Hahn S, Oh TJ, et al. Differences in the HbA1c-lowering efficacy of glucagon-like peptide-1 analogues between Asians and non-Asians: a systematic review and meta-analysis. Diabetes Obes Metab 2014;16:900-9.

33. Miyagawa JI, Odawara M, Takamura T, et al. Once weekly glucagon-like peptide-1 receptor agonist dulaglutide is non-inferior to once daily liraglutide and superior to placebo in Japanese patients with type 2 diabetes: a 26 -week randomised phase 3 study. Diabetes Obes Metab 2015; Jul 14. doi: 10.1111/dom.12534. [Epub ahead of print].

34. Araki E, Inagaki N, Tanizawa Y, et al. Efficacy and safety of once weekly dulaglutide in combination with sulphonylurea and/or biguanide compared with once daily insulin glargine in Japanese patients with type 2 diabetes: a randomised, open-label, phase 3, noninferiority study. Diabetes Obes Metab 2015; Jul 14. doi: 10.1111/dom.12540. [Epub ahead of print].

35. Takamura T, Miyagawa J, Odawara M, et al. Efficacy and safety of once-weekly dulaglutide versus once-daily liraglutide in Japanese patients with type 2 diabetes. Diabetes 2015;64 (Suppl 1):Abstract 1111-P.

36. Weinstock RS, Guerci B, Umpierrez G, et al. Safety and efficacy of once-weekly dulaglutide versus sitagliptin after 2 years in metformin-treated patients with type 2 diabetes (AWARD-5): a randomized, phase III study. Diabetes Obes Metab 2015;17:849-58.

37. Skrivanek Z, Gaydos BL, Chien JY, et al. Dose-finding results in an adaptive, seamless, randomized trial of once-weekly dulaglutide combined with metformin in type 2 diabetes patients (AWARD-5). Diabetes Obes Metab 2014;16:748-56.

38. Syed YY, McCormack PL. Exenatide extended-release: an updated review of its use in type 2 diabetes mellitus. Drugs 2015;75:1141-52.

39. Tuttle KR, McKinney TD, Davidson JA, et al. The effects of once-weekly dulaglutide on kidney function in clinical trials. Diabetes 2015;64 (Suppl 1):Abstract 1114-P.

40. Ferdinand KC, White WB, Calhoun DA, et al. Effects of the once-weekly glucagonlike peptide-1 receptor agonist dulaglutide on ambulatory blood pressure and heart rate in patients with type 2 diabetes mellitus. Hypertension 2014;64:731-7.

41. Ferdinand KC, Sager PT, Atisso CM, et al. Once-weekly dulaglutide does not increase the risk for CV events in type 2 diabetes: a prespecified CV meta-analysis of prospectively adjudicated CV events. Diabetes 2015;64 (Suppl 1):Abstract 1127-P.

42. Matfin G, Van Brunt K, Zimmermann AG, et al. Safe and effective use of the once weekly dulaglutide single-dose pen in injection-naive patients with type 2 diabetes. J Diabetes Sci Technol 2015; 9:1071-9.

43. Trujillo JM, Nuffer W, Ellis SL. GLP-1 receptor agonists: a review of head-to-head clinical studies. Ther Adv Endocrinol Metab 2015;6:19-28.

44. Yabe D, Kuwata H, Usui R, et al. Glucagon-like peptide-1 receptor agonist therapeutics for total diabetes management: assessment of composite end-points. Curr Med Res Opin 2015;31:1267-70.

* 45. Scheen AJ. Which incretin-based therapy for type 2 diabetes? Lancet 2014;384:13257.

Comment about the AWARD-6 study comparing the efficacy of all available GLP-1 receptor agonists in metformin-treated patients with T2DM 
46. Buse JB, Nauck M, Forst T, et al. Exenatide once weekly versus liraglutide once daily in patients with type 2 diabetes (DURATION-6): a randomised, open-label study. Lancet 2013;381:117-24.

47. Pratley RE, Nauck MA, Barnett AH, et al. Once-weekly albiglutide versus once-daily liraglutide in patients with type 2 diabetes inadequately controlled on oral drugs (HARMONY 7): a randomised, open-label, multicentre, non-inferiority phase 3 study. Lancet Diabetes Endocrinol 2014;2:289-97.

48. Scheen AJ. Pharmacokinetics and clinical use of incretin-based therapies in patients with chronic kidney disease and type 2 diabetes. Clin Pharmacokinet 2015;54:1-21.

49. National Institute for health and Care Excellence. Type 2 diabetes: the management of type 2 diabetes: NICE Clinical Guideline 87. 2009; Available from: https://www.nice.org.uk/guidance/cg87. [Accessed July 23, 2015]

50. Agence Nationale des Médicaments et des Produits de Santé. Stratégie médicamenteuse du contrôle glycémique du diabète de type 2 : recommandations. 2013;Available from: http://www.has-sante.fr/portail/upload/docs/application/pdf/201302/10irp04_reco_diabete type_2.pdf. [Accessed July 23, 2015]

51. Jones AG, McDonald TJ, Shields BM, et al. Markers of beta-cell failure predict poor glycemic response to GLP-1 receptor agonist therapy in type 2 diabetes. Diabetes Care 2015; Aug 4. pii: dc150258. [Epub ahead of print].

52. Kozawa J, Inoue K, Iwamoto $\mathrm{R}$, et al. Liraglutide is effective in type 2 diabetic patients with sustained endogenous insulin-secreting capacity. J Diabetes Investig 2012;3:294-7.

53. Usui R, Yabe D, Kuwata H, et al. Retrospective analysis of safety and efficacy of liraglutide monotherapy and sulfonylurea-combination therapy in Japanese type 2 diabetes: Association of remaining beta-cell function and achievement of HbA1c target one year after initiation. J Diabetes Complications 2015; Jul 21. pii: S1056-8727(15)00292-5.

54. Grunberger G, Forst T, Fernandez Lando L, et al. Early fasting glucose measurements can predict later glycaemic response to once weekly dulaglutide. Diabet Med 2015; Jul 14. doi: 10.1111/dme.12833. [Epub ahead of print].

55. Reaney M, Yu M, Lakshmanan M, et al. Treatment satisfaction in people with type 2 diabetes mellitus treated with once-weekly dulaglutide: data from the AWARD-1 and AWARD-3 clinical trials. Diabetes Obes Metab 2015; 17:896-903.

56. Henry RR, Rosenstock J, Logan D, et al. Continuous subcutaneous delivery of exenatide via ITCA 650 leads to sustained glycemic control and weight loss for 48 weeks in metformin-treated subjects with type 2 diabetes. J Diabetes Complications 2014;28:393-8.

57. Egan AG, Blind E, Dunder K, et al. Pancreatic safety of incretin-based drugs--FDA and EMA assessment. N Engl J Med 2014;370:794-7.

58. Holman RR, Sourij H, Califf RM. Cardiovascular outcome trials of glucose-lowering drugs or strategies in type 2 diabetes. Lancet 2014;383:2008-17.

59. Scheen AJ. Cardiovascular safety of albiglutide and other glucagon-like peptide-1 receptor agonists. Lancet Diabetes Endocrinol 2015; 3:667-9.

60. Scheen AJ, Charbonnel B. Effects of glucose-lowering agents on vascular outcomes in type 2 diabetes: A critical reappraisal. Diabetes Metab 2014;40:176-85

61. Ferrannini E, DeFronzo RA. Impact of glucose-lowering drugs on cardiovascular disease in type 2 diabetes. Eur Heart J 2015; 36:2288-96.

62. Health USNIo. Researching Cardiovascular Events With a Weekly Incretin in Diabetes (REWIND). https://clinicaltrials.gov/ct2/show/NCT01394952 (latest access July 20, 2015) 2015.

63. Scheen AJ. GLP-1 receptor agonists or DPP-4 inhibitors: how to guide the clinician? Ann Endocrinol (Paris) 2013;74:515-22. 
64. Trujillo JM, Nuffer W. GLP-1 receptor agonists for type 2 diabetes mellitus: recent developments and emerging agents. Pharmacotherapy 2014;34:1174-86.

65. Carris NW, Taylor JR, Gums JG. Combining a GLP-1 receptor agonist and basal insulin: study evidence and practical considerations. Drugs 2014;74:2141-52.

66. Eng C, Kramer CK, Zinman B, et al. Glucagon-like peptide-1 receptor agonist and basal insulin combination treatment for the management of type 2 diabetes: a systematic review and meta-analysis. Lancet 2014;384:2228-34.

67. Dejgaard TF, Knop FK, Tarnow L, et al. Efficacy and safety of the glucagon-like peptide-1 receptor agonist liraglutide added to insulin therapy in poorly regulated patients with type 1 diabetes--a protocol for a randomised, double-blind, placebo-controlled study: the Lira-1 study. BMJ open 2015;5:e007791.

68. Scott LJ. Liraglutide: a review of its use in the management of obesity. Drugs 2015;75:899-910. 